\title{
Investigation of DNA repair genes in patients with obsessive-compulsive disorder
}

\author{
Ramazan Celik ${ }^{1, A-C}$, Elif Sinem Iplik², B-D , Cem Ismail Kucukali ${ }^{3, B, C}$, Erdem Tuzun ${ }^{3, B, C}$, Bedia Cakmakoglu ${ }^{4, A, C-F}$ \\ ${ }^{1}$ Department of Molecular Medicine, Institute of Experimental Medicine, Istanbul University, Turkey \\ ${ }^{2}$ Department of Pharmaceutical Microbiology, Faculty of Pharmacy, Istanbul Yeni Yuzyil University, Turkey \\ ${ }^{3}$ Department of Neuroscience, Institute of Experimental Medicine, Istanbul University, Turkey \\ ${ }^{4}$ Institute for Experimental Medicine Research, Istanbul University, Turkey \\ A - research concept and design; B - collection and/or assembly of data; C - data analysis and interpretation; \\ $D$ - writing the article; $E$ - critical revision of the article; $F$ - final approval of the article
}

\section{Address for correspondence \\ Bedia Cakmakoglu}

E-mail: bedia@istanbul.edu.tr

\section{Funding sources}

The study was supported by Istanbul University Scientific Research Projects (number 20606).

\section{Conflict of interest}

None declared

\section{Acknowledgements}

The authors wish to thank Istanbul University Scientific Research Projects for supporting the study.

Received on September 18, 2015 Reviewed on April 14, 2016

Accepted on November 3, 2016

\begin{abstract}
Background. Obsessive-compulsive disorder (OCD) is a major psychiatric disorder identified mostly by obsessions and compulsions. Molecular genetic and gene-expression studies focused on familial and twin cases have shown a wide variety of variant genes related to OCD.

Objectives. The aim of the study was to investigate DNA repair genes as potential molecular markers in $O C D$ by evaluating the distribution of polymorphisms of DNA repair genes in $O C D$ patients.

Material and methods. The study included 100 case subjects with OCD and 122 unrelated healthy controls. Genotyping of XRCCI, XRCC3,XPD, XPG, APET and HOGG7 was performed by polymerase chain reactionrestriction fragment length polymorphism.

Results. Significant differences were found for XPD and genotype frequencies. Likewise, the frequency of the XPD Lys+ genotype was significantly increased in the patients as compared to the controls, and carriers of the Lys + genotype had an increased risk for OCD ( $p=0.027)$. The XPD Lys/Lys genotype frequency was also increased in the patients in comparison to the controls $(p<0.001)$. XPD GIn+ frequencies were higher in the controls than in the patients, and carriers of the Gln+ genotype showed decreased levels of OCD risk ( $p<0.001$ ). XPD Lys/Lys genotype frequency and XPD G/n+ frequency are also significantly associated even after Bonferroni correction ( $p<0.008)$.
\end{abstract}

Conclusions. The findings suggest that XPD Lys/Lys might play a facilitating role in the development of OCD.

Key words: polymorphism, obsessive-compulsive disorder, DNA repair, XPD

DOI

10.17219/acem/66698

\section{Copyright}

Copyright by Author(s)

This is an article distributed under the terms of the

Creative Commons Attribution Non-Commercial License

(http://creativecommons.org/licenses/by-nc-nd/4.0/) 
Obsessive-compulsive disorder (OCD) is a major psychiatric disorder characterized by obsessive thoughts of an intrusive and disturbing nature, and compulsions - repetitive stereotypic behaviors usually associated with anxiety or dread. ${ }^{1-3}$

There is considerable evidence suggesting that OCD may have a biological basis. OCD shares similar features with some neurological diseases, such as Huntington's chorea, encephalitis lethargica (von Economo's encephalitis), Parkinson's disease, Tourette syndrome, schizophrenia, Sydenham's chorea, certain epilepsy types and organic brain disorders such as those caused by trauma, ischemia and tumors. ${ }^{4-7}$

Numerous family studies, segregation analyses, twin and linkage studies have been conducted to understand the genetic and molecular mechanisms of OCD. ${ }^{8-11}$ These studies have led to a better understanding of the genetic and environmental factors leading to the development of OCD. However, the impact of DNA repair genes on OCD development has not been investigated. DNA damage resulting from alkylation, deamination and oxidative stress is mainly reversed by the base excision repair (BER) pathway to ensure genome integrity. The human oxoguanine glycosylase 1 (HOGG1), AP endonuclease 1 (APE1) and X-ray repair cross-complementing 1 (XRCC1) genes are involved in the BER pathway. HOGG1 is a BER enzyme that recognizes and excises 8-hydroxydeoxyguanine (8-oxo-dG), whereas $A P E 1$ is the rate-limiting enzyme in the BER pathway. ${ }^{12-15}$ It cleaves 50 DNA abasic sugar residues generated from ionizing radiation and environmental carcinogens. ${ }^{16-18}$ The XRCC genes are involved in different DNA repair processes contributing to genetic stability. ${ }^{19,20}$ XRCC1 acts as a scaffold for other BER enzymes, while XRCC3 encodes RAD-51-like proteins, and is necessary for homologous recombination DNA repair. ${ }^{21}$

The authors hypothesized that genetic alterations in the components of the DNA repair system could be used as a molecular marker for OCD prognosis. This study was aimed at evaluating the distribution of polymorphisms of the DNA repair genes $X R C C 1, X R C C 3, X P D, X P G$, $A P E 1$ and HOGG1 in OCD patients.

\section{Material and methods}

\section{The study population}

OCD subjects were diagnosed according to the criteria in the 1994 American Psychiatric Association Diagnostic and Statistical Manual of Mental Disorders (DSM IV) and were recruited at the Psychiatric Department of Istanbul Erenkoy Psychiatric and Neurological Disorders Hospital (Turkey), which has an inpatient ward for acute psychiatric patients. All the patients' medical histories were taken upon their first admission. Assessments for the diagnosis of OCD were performed by 2 psychiatrists using cross-sectional interviews and case records. All the patients had active symptoms at the time of the study. Patients with a history of neurological or medical disorders that would affect neuropsychological function (i.e., seizures, head trauma, stroke, brain tumor, meningitis) or with a recent history of alcohol or psychoactive drug abuse were excluded. A total of 100 OCD patients were included in the study.

Normal control participants were recruited from a large medical outpatient clinic. Their demographic data, medical and psychiatric history were investigated, and subjects with a diagnosis of any DSM-IV axis I or axis II disorders were excluded. None of the control subjects had a history of medical illness, head injury, neurological disorder, psychiatric disorder or alcohol or substance abuse, and none had a family history of any psychiatric disorder. A total of 122 unrelated healthy controls were included the study.

\section{Measurements, protocol and procedure}

All the subjects were examined using a standardized interview. Assessments were done on a semi-structured socio-demographic form that required patient information regarding the demographic and personal details of the patients and informants, the patients' complaints, the history of the present illness, details of medical or surgical interventions, past history, family history, premorbid personality, physical examination details, a mental status examination, and a diagnostic formulation. The potential cases were interviewed by a psychiatrist, and their medical records were reviewed whenever relevant. Secondly, a consultant psychiatrist audited the $1^{\text {st }}$ phase results, and confirmed or rejected the diagnosis.

To minimize the effect of ethnic differences in gene frequencies, the study participants were chosen from the Turkish population living in the western region of Turkey. The study was approved by the Medical Ethics Committee of Istanbul Medical Faculty, and all the participants gave written informed consent.

\section{Polymorphism analysis}

Blood samples from all the study participants were collected in EDTA-containing tubes. Genomic DNA was extracted from peripheral whole blood using a commercially available kit according to the manufacturer's instructions (PureLink Genomic DNA Mini Kit, Thermo Fisher Scientific Inc., Waltham, USA). Polymerase chain reaction (PCR)/restriction fragment length polymorphism (RFLP) analysis was performed to detect variations in DNA repair genes APE1, HOGG1, XRCC1, $X R C C 3, X P D$ and $X P G$. Appropriate primers were used to amplify the subjects' corresponding gene by PCR, and the reaction products were digested using the appropriate 
Table 1. Characteristics of the OCD patients and controls

\begin{tabular}{|l|c|c|c|c|c|c|}
\multicolumn{1}{c|}{} & $\begin{array}{c}\text { Control } \\
n=122\end{array}$ & $\begin{array}{c}\text { Patients } \\
n=100\end{array}$ & p-value & $x^{2}$ & OR & $95 \% \mathrm{Cl}$ \\
\hline Age & $44.08 \pm 11.2$ & $41.09 \pm 12.1$ & 0.058 & & & \\
\hline Sex (female/male) & $74 / 48$ & $71 / 29$ & 0.107 & 2.59 & 0.63 & $0.35-1.10$ \\
\hline Smoking (\%) (yes/no) & $72.0 / 28.0$ & $64.0 / 36.0$ & 0.327 & 0.96 & 1.44 & $0.69-3.03$ \\
\hline Alcohol use (\%) (yes/no) & $96.0 / 4.0$ & $97.0 / 3.0$ & 0.748 & 0.10 & 0.74 & $0.12-4.59$ \\
\hline
\end{tabular}

standard deviation (SD). Demographic data was compared using Student's ttest and the $\chi^{2}$ test, as required. Relative risk with 95\% confidence intervals $(\mathrm{CI})$ was calculated as the odds ratio (OR). An $\mathrm{OR}>1$ is associated with higher odds of the outcome; an OR $<1$ is associated with lower odds of the outcome; and an OR $=1$ does not affect the odds of the outcome. ${ }^{22}$

enzyme at $37^{\circ} \mathrm{C}$. The digested products were analyzed on $2 \%$ agarose gel stained with ethidium bromide, and examined under transillumination. Two observers, blind to the subjects' diagnoses, read each gel. In case of any conflict, the experiments were repeated.

\section{Statistical analysis}

The statistical analyses were performed using SPSS software (v. 11.5, SPSS Inc., Chicago, USA). Differences in the distribution of DNA repair genotypes or alleles between the patient group and the control group were tested using the $X^{2}$ test; the data was expressed as means \pm

Table 2. The distribution of the APE1, XRCC1, XRCC3, XPD, XPG and HOGG1 genotype frequencies in the OCD patient group and the control group

\begin{tabular}{|c|c|c|c|c|c|}
\hline \multirow{2}{*}{ Polymorphism } & \multicolumn{2}{|c|}{ Controls } & \multicolumn{2}{|c|}{ OCD patients } & \multirow{2}{*}{$p$-value } \\
\hline & $\mathrm{n}$ & $\%$ & $n$ & $\%$ & \\
\hline \multicolumn{6}{|c|}{ APE Asp148Glu rs3136820 } \\
\hline Asp/Asp & 58 & 47.5 & 47 & 47.0 & \\
\hline Glu/Glu & 18 & 14.8 & 10 & 10.0 & \\
\hline Asp/Glu & 46 & 37.7 & 43 & 43.0 & 0.503 \\
\hline \multicolumn{6}{|c|}{ XRCC1 Arg399GIn rs25487 } \\
\hline Arg/Arg & 111 & 91.0 & 83 & 83.0 & \\
\hline$G \ln / G \ln$ & 0 & 0 & 0 & 0 & \\
\hline $\operatorname{Arg} / G / n$ & 11 & 9.0 & 17 & 17.0 & 0.075 \\
\hline \multicolumn{6}{|c|}{ XRCC3 Thr241Met rs861539 } \\
\hline Thr/Thr & 15 & 12.3 & 5 & 5.0 & \\
\hline Met/Met & 28 & 23.0 & 12 & 12.0 & \\
\hline Thr/Met & 79 & 64.8 & 83 & 83.0 & 0.009 \\
\hline \multicolumn{6}{|c|}{ XPD Lys751GIn rs1052559 } \\
\hline Lys/Lys & 42 & 34.4 & 60 & 60.0 & \\
\hline$G \ln / G \ln$ & 17 & 13.9 & 5 & 5.0 & \\
\hline Lys/Gln & 63 & 51.6 & 35 & 35.0 & 0.000 \\
\hline \multicolumn{6}{|c|}{ XPG Asp1104His rs17655 } \\
\hline Asp/Asp & 69 & 56.6 & 45 & 45.0 & \\
\hline His/His & 13 & 10.7 & 17 & 17.0 & \\
\hline Asp/His & 40 & 32.8 & 38 & 38.0 & 0.175 \\
\hline \multicolumn{6}{|c|}{ HOGG1 Ser326Cys rs1052133 } \\
\hline Ser/Ser & 74 & 60.7 & 56 & 56.0 & \\
\hline Cys/Cys & 3 & 2.5 & 0 & 0 & \\
\hline Ser/Cys & 45 & 36.9 & 44 & 44.0 & 0.187 \\
\hline
\end{tabular}

In addition to this, minor allele frequency and HardyWeinberg equilibrium were calculated by Haploview 4.2 software (The Broad Institute, Cambridge, USA). Linkage disequilibrium among DNA repair gene polymophisms was assessed using $D^{\prime}$ and $r^{2}$ values obtained through the Haploview program. Multiple comparisons were controlled using the Bonferroni correction. P-values $<0.05$ were considered statistically significant.

\section{Results}

Table 1 shows the characteristics of the patient and control groups. The controls and patients were adjusted for age, sex, smoking habit, and alcohol use $(\mathrm{p}<0.05)$.

The distribution of APE1, XRCC1, XRCC3, XPD, XPG and $H O G G 1$ genotype frequencies in the OCD patients and controls is shown in Table 2. Significant differences were found only for the XPD Lys751Gln and XRCC3 Thr241Met ( $\mathrm{p}<0.05)$ genotype frequencies. As compared to the controls, the OCD patients had statistically higher frequencies of the XRCC3 Thr+ genotype (88\% vs $77.1 \%$, $\mathrm{p}=0.03, \mathrm{X}^{2}: 4.46$, OR: $2.18,95 \%$ CI: $\left.1.04-4.56\right)$ and $X R C C 3$ Thr/Met genotype (83\% vs 64.8\%, $\mathrm{p}=0.002, \mathrm{X}^{2}: 9.27$, OR: 2.65, 95\% CI: 1.40-5.04). Likewise, XPD Lys+ genotype frequency was significantly higher in the patients (95\%) than in the controls (86\%); and carriers of the Lys+ genotype ( $\mathrm{p}=0.027, \mathrm{x}^{2}: 4.91$, OR: $\left.3.07,95 \% \mathrm{CI}: 1.09-8.66\right)$ had a 3 times higher risk of OCD. Also, Lys/Lys genotype frequency ( $\mathrm{p}=0.000, \mathrm{x}^{2}: 14.72$, OR: $2.85,95 \% \mathrm{CI}: 1.65-4.93$ ) was higher in the patients $(60 \%)$ than in the controls (34.4\%). Although the OCD patients showed trends toward displaying higher frequencies of XRCC1 Gln+ as compared to the controls ( $17 \%$ vs $9 \%$ ), this difference did not reach statistical significance.

$X P D G \ln +$ frequency $\left(\mathrm{p}=0.075, \mathrm{X}^{2}: 3.17\right.$, OR: $2.06,95 \%$ CI: 0.91-4.64) was increased in the controls (65.6\%) compared with the patients (40\%); and carriers of the Gln+ genotype ( $\mathrm{p}<0.001, \mathrm{x}^{2}$ : 14.47, OR: $0.35,95 \% \mathrm{CI}: 0.20-$ $0.60)$ had a 2.8-fold lower risk of OCD. Gln/Gln genotype frequency ( $\mathrm{p}=0.027, \mathrm{X}^{2}:$ 7.91, OR: 0.32, 95\% CI: 0.11-0.91) was higher in the controls (13.9\%) than in the patients (5\%). Moreover, Lys/Gln genotype frequency ( $\mathrm{p}=0.013$, $X^{2}:$ 6.17, OR: 0.32 , 95\% CI: 0.29-0.86) was significantly higher in the controls (51.6\%) than in the patients (35\%). There were no statistically significant differences 
Table 3. Minor allele frequencies and the distribution of APE1, XRCC1, XRCC3, XPD, XPG and HOGG1 allele frequencies in the OCD patients and the controls

\begin{tabular}{|l|c|c|c|c|c|c|c|}
\multicolumn{1}{|c|}{ SNP } & Rs number & HW p-value & MAF & $\begin{array}{c}\text { Associated } \\
\text { alleles }\end{array}$ & $\begin{array}{c}\text { Case, } \\
\text { control ratios }\end{array}$ & $X^{2}$ & $p$-value \\
\hline Ape Asp148Glu & rs1130409 & 0.231 & 0.327 & Asp & $0.685,0.664$ & 0.222 & 0.6377 \\
\hline XRCC1 Arg399GIn & rs25487 & 0.806 & 0.063 & Gln & $0.085,0.045$ & 2.964 & 0.0851 \\
\hline XRCC3 Thr241Met & rs861539 & $<0.001$ & 0.455 & Thr & $0.465,0.447$ & 0.148 & 0.7004 \\
\hline XPD Lys751Gln & rs1052559 & 0.981 & 0.32 & Lys & $0.775,0.602$ & 15.042 & $<0.001$ \\
\hline XPG Asp1104His & rs17655 & 0.011 & 0.311 & His & $0.360,0.270$ & 4.111 & 0.0426 \\
\hline HOGG1 Ser326Cys & rs1052133 & 0.004 & 0.214 & Cys & $0.220,0.209$ & 0.079 & 0.7789 \\
\hline
\end{tabular}

MAF - minor allele frequency; HW - Hardy-Weinberg equilibrium.

Table 4. The frequencies of haplotypes of DNA repair genes in the patients and the controls

\begin{tabular}{|l|c|c|c|c|c|}
\multirow{2}{*}{ Number of haplotype } & \multicolumn{5}{|c|}{ Frequency } \\
\cline { 2 - 6 } & overall & patients & control & $X^{2}$ & p-value \\
\hline XRCC1 Arg: XPG Asp & 0.654 & 0.598 & 0.701 & 5.138 & 0.023 \\
\hline XRCC1 Arg: XPG His & 0.283 & 0.317 & 0.254 & 2.145 & 0.143 \\
\hline XRCC1 GIn:XPG Asp & 0.035 & 0.042 & 0.029 & 0.579 & 0.447 \\
\hline XRCC1 GIn:XPG His & 0.028 & 0.043 & 0.016 & 2.839 & 0.092 \\
\hline
\end{tabular}

ing it one of the most common and serious mental conditions. ${ }^{25-27}$ Although the exact causes of OCD are unknown, data from family studies suggests the presence of a heritable factor, and implies that genetic factors might account for around $50 \%$ of OCD symptoms. Moreover, polymorphisms of certain genes have been associated with OCD. ${ }^{15,23,28}$ The present study attempted to unravel potential as-

between the OCD patients and the controls with regard to XPG Asp1104His and HOGG1 Ser326Cys genotype frequencies $(\mathrm{p}>0.05)$ (Table 2). Nevertheless, the XPD genotype and the distribution of XPD Lys/Lys genotype frequency and XPD Gln+ frequency are significantly associated due to the Bonferroni correction. XRCC3 is not included in the statistical results because it was not in accordance with Hardy-Weinberg equilibrium.

The distribution of APE1, XRCC1, XRCC3, XPD, XPG and HOGG1 allele frequencies in the OCD patients and the control group is shown in Table 3. XPG His and XPD Lys allele frequencies were significantly higher in the patients than in the controls.

Minor allele frequency (MAF) values are also given in Table 3. With the exception of the XRCC3 Thr241Met genotype, the distribution of all allele and genotype frequencies among the patients and the controls was in accordance with Hardy-Weinberg equilibrium.

When the results were analyzed in terms of haplotype frequencies, the only significant difference between the controls and the patients was found in the haplotype with XRCC1 Arg: XPG Asp (Table 4). There was a weak linkage disequilibrium between the XRCC1 and XPG polymorphisms (D': 0.198, logarithm of odds (LOD): 0.33, $\mathrm{r}^{2}$ : 0.006).

\section{Discussion}

OCD is a widespread psychiatric disorder that is characterized by disabling obsessions and/or compulsions. ${ }^{24}$ Originally thought to be rare, OCD is now known to have a lifetime prevalence around 1-3\% worldwide, maksociation between DNA repair genes and OCD. To the authors' knowledge, this is the first study focused on the potential contribution of XRCC1,XRCC3, XPD, XPG, $A P E 1$ and HOGG1 genotypes to OCD pathogenesis.

The study found that certain $X P D$ gene polymorphisms might have a facilitating or protective role in OCD development. These results not only suggest that DNA repair mechanisms somehow influence the neuronal pathways controlling behaviors, but also lend further support to a biological basis of OCD.

Exposure to certain chemicals such as hydrocarbons, aryl amines and nitrosamines might result in the formation of reactive oxygen species as by-products, which might ultimately affect DNA functions. DNA repair mechanisms are thus of paramount importance in reversing alterations to DNA and providing unmutated DNA during the replication process. More than a hundred genes are known to participate in DNA repair mechanisms. ${ }^{29-31}$ Biological models of OCD propose anomalies in the dopamine and serotonin pathways of the brain. ${ }^{32}$ At least in some patients, OCD might plausibly be the end result of mesocortical pathway dysfunction caused by a variety of factors such as trauma, infections and autoimmunity. Increased generation of reactive oxygen species as a result of impaired DNA repair mechanisms might be rendering the dopaminergic mesocortical pathway more susceptible to these environmental factors. Recent findings on the association between DNA repair gene polymorphisms and Parkinson's disease, which is also related to dopaminergic pathways, support this hypothesis. ${ }^{33}$ It is also possible that XPD genes have some yet unknown function in dopamine and/or serotonin metabolism. 
According to human brain tissue studies, DNA damage has been found at increasingly high levels in nervous system disorders, adding to the importance of the present study to research investigating OCD mechanisms. ${ }^{34-38}$ It is possible to say that there might be an important relationship between the DNA repair system and neurodegeneration. This area should be investigated further in large-scale studies to focus specifically on identifying which repair system is related to the disease mechanism.

\section{Conclusions}

The findings of the current study suggest that certain $X P D$ genotypes are associated with the development of OCD. Further studies with larger sample groups are necessary to clarify the significance of these gene variants. Moreover, the mechanisms by which these genes contribute to OCD pathogenesis need to be clarified.

\section{References}

1. Nestadt G, Grados M, Samuels JF. Genetics of OCD. Psychiatr Clin North Am. 2010;33:141-158.

2. Nestadt G, Samuels JF, Romanoski AJ, et al. Obsessions and compulsions in the community. Acta Psychiatr Scand. 1994;89:219-224.

3. Nestadt G, Bienvenu OJ, Cai G, et al. Incidence of obsessive-compulsive disorder in adults. J Nerv Ment Dis. 1998;186:401-406.

4. Steketee G. Disability and family burden in obsessive-compulsive disorder. Can J Psychiatry. 1997;142:919-928.

5. Pauls DL. The genetics of obsessive compulsive disorder: A review of the evidence. Am J Med Genet Part C Semin Med Genet. 2008;148:133-139.

6. Pauls DL. The genetics of obsessive-compulsive disorder: A review. Dialogues Clin Neurosci. 2010;12:149-163.

7. Stein DJ. Advances in the neurobiology of obsessive-compulsive disorder: Implications for conceptualizing putative obsessive-compulsive and spectrum disorders. Psychiatr Clin North Am. 2000;23:545-562.

8. Black DW, Noyes R Jr. Goldstein RB, et al. A family study of obsessive-compulsive disorder. Arch Gen Psychiatry. 1992;49:362-368.

9. Pauls DL. The genetics of obsessive compulsive disorder: A review of the evidence. Dialogues Clin Neurosci. 2010;12(2):149-163.

10. Fyer AJ, Lipsitz JD, Mannuzza S, Aronowitz B, Chapman TF. A direct interview family study of obsessive-compulsive disorder I. Psychol Med. 2005;35:1611-1621.

11. Wendland JR, Moya PR, Kruse MR, et al. A novel, putative gain of function haplotype at SLC6A4 associates with obsessive-compulsive disorder. Hum Mol Genet. 2008;17:717-723.

12. Krupa R, Sobczuk A, Popławski T, Wozniak K, Blasiak J. DNA damage and repair in endometrial cancer in correlation with the HOGG1 and RAD51 genes polymorphism. Mol Biol Rep. 2011;38(2):1163-1170.

13. Ashton KA, Proietto A, Otton G, et al. Estrogen receptor polymorphisms and the risk of endometrial cancer. BJOG. 2009;116(8): 1053-1061.

14. Attar R, Cacina C, Sozen S, Attar E, Agachan B. DNA repair genes in endometriosis. Genet Mol Res. 2010;9(2):629-636.

15. Wood RD, Mitchell M, Sgouros J, Lindahl T. Human DNA repair genes. Science. 2001;291(5507):128-129.

16. Wang $M$, Qin C, Zhu J, et al. Genetic variants of XRCC1, APE1, and ADPRT genes and risk of bladder cancer. DNA Cell Biol. 2010;29(6):303-314.
17. Robertson $A B$, Klungland $A$, Rognes $T$, Leiros I. DNA repair in mammalian cells. Base excision repair: The long and short of it. Cell Mol Life Sci. 2009;66(6):981-993.

18. Li Z, Guan W, Li MX, et al. Genetic polymorphism of DNA baseexcision repair genes (APE1, OGG1 and XRCC1) and their correlation with risk of lung cancer in a Chinese population. Arch Med Res. 2011;42(3):226-234.

19. Canbay E, Cakmakoglu B, Zeybek U, et al. Association of APE1 and HOGG1 polymorphisms with colorectal cancer risk in a Turkish population. Curr Med Res Opin. 2011;7(7):1295-1302.

20. Chang-Claude J, Popanda O, Tan XL, et al. Association between polymorphisms in the DNA repair genes, XRCC1, APE1, and XPD and acute side effects of radiotherapy in breast cancer patients. Clin Cancer Res. 2005:11(13):4802-4809.

21. Blasiak J, Synowiec E, Salminen A, Kaarniranta K. Genetic variability in DNA repair proteins in age-related macular degeneration. Int J Mol Sci. 2012;13:13378-13397.

22. Szumilas M. Explaining odds ratios. J Can Acad Child Adolesc Psychiatry. 2010;19:3.

23. Salah GB, Fendri-Kriaa N, Kamoun H, Kallabi F, Mkaouar-Rebai E, Fourati $A$. An interethnic variability and a functional prediction of DNA repair gene polymorphisms: The example of XRCC3 (p.Thr241>Met) and XPD (p.Lys751>Gln) in a healthy Tunisian population. Mol Biol Rep. 2012;39:9639-9647.

24. Calvocoressi L, Libman D, Vegso SJ, McDougle CJ, Price LH. Global functioning of inpatients with obsessive-compulsive disorder, schizophrenia, and major depression. Psychiatric Services. 1998;49:379-381.

25. Karno M, Golding JM, Sorenson SB, Burnam MA. The epidemiology of obsessive-compulsive disorder in five U.S. communities. Arch Gen Psychiatry. 1988;45:1084-1099.

26. Weissman MM, Bland RC, Canino GJ, et al. The cross national epidemiology of obsessive compulsive disorder. J Clin Psychiatry. 1994:55:5-10.

27. Eaton WW, Martins SS, Nestadt GO, Bienvenu OJ, Clarke D, Alexandre P. The burden of mental disorders. Epidemiol Rev. 2008;30:1-14.

28. Shugart YY, Samuels J, Willour VL, et al. Genomewide linkage scan for obsessive-compulsive disorder: Evidence for susceptibility loci on chromosomes 3q, 7p, 1q, 15q, and 6q. Molecular Psychiatry. 2006;11:763-770.

29. Benhamou S, Sarasin A. ERCC2/XPD gene polymorphisms and lung cancer: A HuGE review. Am J Epidemiol. 2005;161:1-14.

30. Friedberg EC. DNA damage and repair. Nature. 2003;421:436-440.

31. Wood RD, Mitchell M, Sgouros J, Lindahl T. Human DNA repair genes. Science. 2001;291:1284-1289.

32. Olver JS, O'Keefe G, Jones GR, et al. Dopamine D(1) receptor binding in the anterior cingulate cortex of patients with obsessive-compulsive disorder. Psychiatry Res. 2010;83:85-88.

33. Gencer M, Dasdemir S, Cakmakoglu B, et al. DNA repair genes in Parkinson's disease. Genet Test Mol Biomarkers. 2012;16:504-507.

34. Dobbin MM, Madabhushi R, Pan L, et al. SIRT1 collaborates with ATM and HDAC1 to maintain genomic stability in neurons. Nat Neurosci. 2013;16(8):1008-1015.

35. Wang WY, Pan L, Su SC, et al. Interaction of FUS and HDAC1 regulates DNA damage response and repair in neurons. Nat Neurosci. 2013;16(10):1383-1391.

36. Weissman L, Jo DG, Sorensen MM, et al. Defective DNA base excision repair in brain from individuals with Alzheimer's disease and amnestic mild cognitive impairment. Nucleic Acids Res. 2007;35(16):5545-5555.

37. Fishel ML, Vasko MR, Kelley MR. DNA repair in neurons: So if they don't divide, what's to repair? Mutat Res. 2007;614(1-2):24-36.

38. Coppede F, Migliore L. DNA damage and repair in Alzheimer's disease. Curr Alzheimer Res. 2009;6(1):36-47. 